\title{
Karen Collins (Ed.): From pac-man to pop music. Interactive audio in games and new media. Hampshire: Ashgate Publishing. 2008
}

\section{Vitus Vestergaard}

\author{
MedieKultur 2010, 48, 148-151
}

\section{Published by SMID | Society of Media researchers In Denmark | www.smid.dk} The online version of this text can be found open access at www.mediekultur.dk

For manden på gaden vil et emne som interaktiv lyd synes ret nichepræget og snævert. Antologien From Pac-man to Pop Music viser dog tydeligt, at dette ikke er tilfældet. Emnet er i virkeligheden meget bredt, og denne bredde er helt naturligt blevet inkorporeret som et grundlæggende karakteristika for antologien.

I forordet gør Collins det klart, at målet med bogen er - på tværfaglig vis - at give et overblik over forskellige aspekter af emnet "games audio" fra en række perspektiver. Mange vil nok studse over brugen af begrebet "games audio" som beskrivelse af bogens emne; og med god grund. Det virker nemlig en smule obskurt, hvilke domæner bogen egentlig fokuserer på, og det bliver hurtigt tydeligt, at spil blot er ét af dem. Antologiens undertitel lyder "Interactive audio in games and new media", mens bagsideteksten taler om "video games, but also web pages, theme parks, museums, art installation and theatrical events". Længere nede i bagsideteksten loves vi, at bogen tilbyder "a fresh perspective on media music, one that will complement film studies". Og kigger man i indholdsfortegnelsen, viser det sig, at også mobiltelefoni og ringetoner har fået et separat afsnit i bogen.

Så hvad handler bogen egentlig om? Dette besvares nok bedst ved at se på antologiens struktur. Bogen består af 12 artikler, som er fordelt på fem dele:

Første del, Industries and synergies, omhandler de synergier, der er opstået mellem musik- og spilindustrien, hvor populærmusik markedsføres gennem spil, og hvor spil anvender populærmusik til at ramme bestemte målgrupper.

Anden del, Ringtones and mobile phones, handler om mobiltelefonen som spilplatform 
og som lydmedie. Som i første del er der også tråde til den kommercielle verdens salg og distribution af populærmusik - her som ringetoner.

Tredje del, Instruments and interactions, fokuserer trods overskriften på komposition. Her drejer det sig om mulige teknikker og tilgange til dynamisk musik, det være sig musik, som er algoritmisk eller adaptiv.

Fjerde del, Techniques and technologies, handler om mere lydtekniske løsninger på æstetiske problematikker i spil, såsom mixing i realtid og klanglig variation. Sidstnævnte behandles $i$ et kapitel om anvendelse af granulær lydsyntese i spil.

Femte og sidste del, Audio and audience, vender blikket mod brugeren. Det handler både om medskabende musikbrug i demoscenen, om perception af lyd i spil samt om musikteoretiske aspekter ved brugen af musikbaserede spil som Guitar Hero.

Med sine i alt 224 sider virker omfanget meget rimeligt, selv om der nok var plads til lidt flere artikler. Det skyldes dog ikke mangel på artikler, at det efter nøje gennemlæsning stadig er svært at sige præcis, hvad antologien egentlig handler om. Nej, det skyldes ene og alene bredden. Et hurtigt blik på forfatterlisten taler sit eget tydelige sprog mht. bredde: Her er alt lige fra autodidakte lyddesignere og komponister til teoretikere med fagligt ståsted i medievidenskab, datalogi og musikvidenskab. Og meget kendetegnende for feltet dækker mange af bidragyderne adskillige fagligheder og kombinerer teori og praksis i deres daglige virke.

Om dette tværfaglige felt skriver Collins selv, at det måske er stedet, hvor en ny disciplin opstår: I et møde mellem et væld af teoretiske og praktiske tilgange, hvor diskussioner og meninger kan vokse og udvikles. Hun refererer flere gange til litteraturen omkring filmlyd og -musik, og hun påpeger, at det meste litteratur omkring lyd i spil trækker på teorier og praksisser fra filmverdenen, hvilket hun har helt ret i. Men hvis et af antologiens mål er at vriste sig helt fri af denne arv, slår det fejl: Det er en tung arv, som skinner igennem i flere af artiklerne. Litteraturlisten afslører også masser af referencer til filmlydens kendte teoretikere som Rick Altman, Michel Chion og Claudia Gorbman. Dette er dog helt på sin plads, for filmlyd er i særdeleshed et af fundamenterne for digital lyd i spil og andre digitale medier. Det samme kan siges om elektroakustisk musik og computermusik, og også her kan man i antologien finde klare bånd og referencer, f.eks. til Curtis Roads og Barry Truax.

Antologien skitserer således et meget komplekst felt, og den indeholder små bidder af alle de fagligheder og traditioner, som studier af lyd i digitale medier kræver kendskab til. Så bredden er som minimum en fordel, hvis ikke den ligefrem er en nødvendighed.

Spørgsmålet er så, om bredden leveres på bekostning af dybde. Men det mener jeg ikke er tilfældet. Hver artikel kan ses som et specifikt nedslag i den digitale lydverden, og alle artiklerne leverer en forholdsvis målrettet og konkret behandling af et delemne. I nogle tilfælde drejer det sig om en konkret case som i Antti-Ville Kärjäs artikel "Marketing music through computer games: The case of Poets of the Fall and Max Payne 2". Her analyseres sammenhængen mellem det finske band Poets of the Falls pludselige succes og anvendelsen af en af deres sange i spillet Max Payne 2 (2003). 
I andre tilfælde drejer det sig om konkrete teknikker, såsom granulær syntese i Leonard J. Pauls "An introduction to granular synthesis in video games" eller markup-formatet AMML i Guerraz \& Lemordants "Indeterminate adaptive digital audio for games on mobiles". Der er dog tale om viden på meget forskellige niveauer. Pauls artikel er vitterligt en introduktion til granulær syntese - en syntesemetode, hvor lyde dannes af små bidder: de såkaldte "gran". Det er en klar fremstilling af denne specifikke metode, men den viden, læseren får, er meget generel og uafhængig af teknologiske platforme. Omvendt er Guerraz \& Lemordants artikel særdeles unik og næppe relevant som mere end en øjenåbner for alle andre end de, som måtte arbejde med lyd i Java på mobiltelefoner. Og om få år er artiklen formentlig slet ikke relevant overhovedet. Men det virker som et frisk pust, at antologien alligevel indeholder den type artikler, og det vidner om, at bogen forholder sig til aktuelle debatter og udviklingsprocesser.

Populært sagt indeholder From Pac-man to Pop Music noget for enhver. Men samtidig vil alle også kunne finde mindst én artikel, som ikke synes relevant eller interessant. Det er vilkårene, når man sigter så bredt. Generelt virker artiklerne meget letlæste, og selv de mere teknologisk orienterede vil sagtens kunne bruges i undervisning på bachelor-niveau.

Der er dog enkelte irritationsmomenter, som forstyrrer den ellers behagelige læsning. Først og fremmest er der en del småfejl. Her er både tale om fejl i korrekturlæsningen og fejl i brugen af begreber. Et eksempel på førstnævnte er brugen af ordet "note", hvor der i virkeligheden mentes "node" (p. 77). I en tekst, som handler om multilineær musik, får det en til at stoppe op, for begge ord tilhører emnets vokabularium. Og selv om man godt kan gennemskue, hvad der menes, er den slags fejl generende for ens læsning. Der er også mange mere ligegyldige trykfejl samt fejl i referencer til figurer. Eksempelvis refereres der til en lysegrå del af en figur, som i bogen kun indeholder kulsort og kridhvid (p. 64). Et eksempel på begrebslige fejl er, når begrebet "CD-ROM audio" bruges som modsætning til syntese (p. 4). Her blandes et lagringsmedie pludselig sammen med en metode til lydgenerering. Dette er noget konceptuelt roderi, som ikke ødelægger forståelsen af teksten, men som gør, at man bremser op i irritation.

Dernæst er der et irritationsmoment i graden af indforståethed. Nogle af bogens passager er meget indforståede, mens andre synes lidt banale. Det ligger i sagens natur, at det er umuligt at ramme alle læsere på det niveau, hvor de befinder sig. Men der er stadig en øvre og nedre grænse for indforståethed. En artikel refererer f.eks. til en anden artikel, som taler om "This new Boulezian model of musical structure" (p. 86). Det eneste, vi her får at vide, er, at Boulez (som er en nulevende fransk komponist) introducerede interaktivitet i musikalsk form. Resten må læseren tænke sig til. I en antologi, som handler om interaktiv lyd, ville det være mere end interessant at få at vide, hvordan Boulez gjorde sin musik interaktiv. Det tager ikke lang tid at forklare, hvorledes dette sker ved at lade musikudøveren træffe forskellige valg undervejs i fremførelsen. I den anden ende af skalaen indeholder antologien passager, som virker lidt redundante; som når vi gennem adskillige linjer får forklaret, hvad ordet "synergi" betyder med fulde referencer til Oxford English Dictionary (p. 30). 
Ser man bort fra disse små irritationsmomenter, skal der ikke herske nogen tvivl om, at From Pac-Man to Pop Music er en yderst anbefalelsesværdig og interessant antologi. Bredden er ambitiøs, men det fungerer godt at anlægge både praktiske og teoretiske vinkler på feltet gennem mange dybt forskellige optikker. Antologien grundlægger ikke en ny disciplin, men den omkranser fint et felt, som allerede er sprællevende. Det er forståeligt, at bogen er lidt inkonsekvent i brugen af termen "games audio", for feltet er bredere end blot spil. Hvad enten man så vælger at kalde det "studier i digital lyd" eller noget helt andet, så er From PacMan to Pop Music en glimrende introduktion. For os, som allerede er blevet introduceret til feltet, byder bogen stadig på mange guldkorn, og artiklerne anlægger så forskellige vinkler på feltet, at bogen ikke kan undgå at udvide ens faglige horisont.

Vitus Vestergaard

Ph.D.-stipendiat

Institut for Litteratur, Kultur og Medier

Syddansk Universitet, Danmark

vitus@dream.dk 